\title{
The intellectual transformation of modern design discourses in the Eastern Mediterranean Region (EMR)
}

\author{
SAAD, Qassim \\ School of Design and the Built Environment-Curtin University-Perth, Western Australia \\ qassim.saad@curtin.edu.au \\ doi: 10.21606/pluriversal.2020.014
}

\begin{abstract}
This study will offer an overview of applied discourses of design in the Eastern Mediterranean Region (EMR), including Egypt, Palestine, Lebanon, Syria, Jordan, and Iraq. Since the 1940s, these countries have been known for their pioneering statues, creative engagements, and influence on shaping, resourcing, and sustaining the emergent project of modernity in the EMR. Studies of these countries' contemporary design discourses are underdeveloped, with extremely limited studies addressing their context and practices. This study will survey identical phases throughout the contemporary history of these countries, exploring and critically reviewing key themes in their regional sociopolitical rhetoric since the 1950s. The study demonstrates the need to utilise design discourses to empower regional societies currently facing unrest. The study identified four thematic periods reflecting the influence of regional sociopolitical rhetoric: (1) the colonisation era, articulating a sociocultural perspective concerning craftmaking and craftsmanship; (2) postcolonisation and the emergence of modernity, with design emerging as a cultural manifestation that enhances regional socioeconomic development; (3) the rise of the national state, with design as a sociopolitical manifestation utilised to reinforcing identity and local traditions; (4) expansion of autocracy and current discord, with the emergence of social design. These thematic periods are explored through selected examples from across the EMR.
\end{abstract}

Design in the Eastern Mediterranean, Postcolonial Design, Modern Design, Design and Social Context

\section{Colonial influences on the emergence of modernity in the EMR}

During World War I (WWI), geopolitical and economic factors directed the European colonial powers to arbitrarily draw borders dividing the EMR into new states based on the 1916 Sykes-Picot Agreement. These borders have remained a major source of conflict and instability in the region since their

This work is licensed under a Creative Commons Attribution-NonCommercial-Share Alike 4.0 
inception. Colonial mandates were formally granted in 1922, when the League of Nations gave Britain sovereignty over Iraq and Jordan, and France was given sovereignty over Syria and Lebanon. At the turn of 20th Century, a sense of cultural hope was revived in the region when the slow emergence of direct and indirect communication channels between Arabs and Europe expanded the number of European books, periodicals, and newspapers available to Arab readers. Moreover, new opportunities were available for Arabic students to continue their studies at European Institutions-many waves of migrants from Syria, Lebanon, and Egypt were departing their lands to go to the 'new world.' The expansion of communication with Europe and America supported efforts by Arabic authors to engage in writing and to "express in Arabic their consciousness of themselves and their place in the modern world." (Hourani, 2005, P. 503) Furthermore, Western modernity emerged in the region where Western notions of progress in science, technology, art, and social systems were introduced. Still, religion at that time fuelled reactions against applications and practices rooted in Western modernity, where movements across the EMR "acquire[d] the strength to confront Europe and become part of the modern world." (Hourani, 2005, p. 503) A challenging debate developed between traditional Islamic thinkers and new, educated, local social leaders regarding the alignment of modernity with Islamic principles in education and sociocultural practices, based on the fact "modernity is Western, and imperial powers have imposed the Western ways of thought associated with it on the Middle East." (Helfont, 2015) Simultaneously, this era addressed the rise of nationalist political beliefs that guided civil leaders to seek European support in their attempts to detach from the hegemony of the Ottoman Empire. European attitudes promoted the self-determination of national entities and created a new Arabic political identity that justified their mandate agreements. Furthermore, support progressed toward modernisation of these new territories and shifted them from isolation into part of the new world, which articulated the major arguments justifying and legalising Western colonisation of the region (al-Musawi, 2006).

The roots of modern cultural practices in the EMR emerged from European influences; for example in Egypt, with early French invasion (1798-1801) through to British colonialism (1882-1922). The modern cultural influence of both these colonial powers intersected with the rich ancient history of Egypt, resulting in modern Egyptian sociocultural practices represented through the local style of artefacts and architecture. Egypt offered a sustained incubator for rich and ancient traditions of craftsmanship and skilled artisans. Historical evidence describes how in the 1670 s "Cairo already possessed a remarkable number of guilds: among the multitude of artisan groups (taife) recorded by Evliya Celebi, 262 units have been identified as associations encompassing the traders and artisans of Cairo proper, excluding those of Bulaq and other satellite towns." (Faroqhi, 2012, p. 129) This foundation welcomed and offered support to the 'modern' concept of applied arts introduced in the early $20^{\text {th }}$ Century and was represented by vocational education institutions established in Cairo at that time ${ }^{1}$. Craftsmen's practices, along with social preferences, significantly influenced the teaching methods and content of applied arts. This resulted in program content being overloaded with artists' and craftsmen's teaching methods and concepts. It was deeply concerned with construction under supervision, following the master as a source of knowledge and skilled coach. Therefore, applied arts education transformed into higher education with arts and crafts-oriented curricula delivering a number of programs based on the making of artefacts, production skills, and technology ${ }^{2}$. Applied arts graduates, known locally as applied

\footnotetext{
1 The first vocation school was established in Cairo in 1839. In 1909, the school created a new study program focused on craft and arts, which supported the development of artisan practices.

2 In 1932, the School of Vocational Education changed its name to The School of Arts. Then in 1942, it was called the higher school of Applied Arts. The school linked with the University of Helwan (state-funded university) in 1975 and become the Faculty of Applied Arts. Which makes it now known as the "mother of all applied arts faculties" in Egypt.

http://www.helwan.edu.eg/Applied-Arts/ Retrieved 4th/Nov./2019
} 
artists, were capable of maintaining traditional artisan heritage while utilising new technologies to make and produce ornamented craft objects for both locals and tourists. One of the main categories traditional Egyptian applied arts graduates are pigeonholed into is that of 'artistic craftsman'. Such craftsmen are qualified in imitating existing artwork under the supervision of a master.

Although applied arts programs in Egypt were positioned as a pioneering model that could be replicated throughout the EMR, established programs in the region during the 1970s didn't use the term 'applied arts.' Instead, these programs used the term 'design' in their titles as a cultural statement, identifying with the modern context and producing prestigious graduates with knowledge to design and make ornamental objects. The similarity between design schools in the region and Egyptian applied arts institutions was related to their context and practices; both relied on arts and crafts as major components in their curricula, learning outcomes, and teaching practices. This is understandable, as the majority of design schools in the region were established according to the Egyptian applied arts model and many had a high proportion of Egyptian academic staff. In fact, they were the founders and leaders of many of these schools during the established periods. Studies of design discourses in Egypt and the region are rare, with extremely limited information on the context and practices of that era. The limited number of local publications (the majority in Arabic) were overwhelmed with the presentation of design knowledge and practices aligned with traditional local culture and social norms. Such design is intensely dependent on artistic foundations and know-how concerning crafts and artisan skills, and "their benefit in adding value to man-made objects through surface ornamentation." (Chadirji, 1995, p.178)

\section{Postcolonialism: Enforced modernity and technological transformation}

Geopolitically, the postcolonial nation states in the EMR were considered fragile entities, their existence and capacity to stabilise influenced by many internal and external factors, considering that "postcolonial societies... are said to be strong, in that people rely on social networks rather than the state to meet their needs... they rely on tribes or villages notables. As a result, it has been difficult for these states to carry out their policies and they have often had to resort to violence." (Helfont, 2015) Instability has continued in EMR countries due to age-old problems and factors, leading to the dynamic and meta-complex nature seen today. In Iraq, Britain formed the Kingdom of Iraq under the mandate system via the Anglo-Iraqi treaty. Britain followed the same process and established a kingdom in Jordan. Both the Iraqi and Jordanian kingdoms were ruled by the same family, and according to Cannadin (2002) they were "explicitly conceived on the model of the Indian princely states." (p.p. 71-72) After the post-WWI formation of the new EMR states, there were two main visions for what social and political systems they should follow, both of which continued to have proponents after the independence of Iraq and Syria, in particular. One of these ideologies is 'Pan-Arab nationalism,' which holds that the era of the Islamic Caliphate stands as the greatest historical example of Arab unity and reviving this unity is the best way for Arabs to become an effective power in the modern era. Conversely, there were the nationalist ideologies such as 'Iraqi Nationalism,' (AlSayyad, 2008, p.260) which was the main competing ideology. Iraqi Nationalism perceives Iraq's Arab heritage to be only one part of its identity, and that this identity has been formed by the long history of civilisation in the region: Sumerian, Babylonian, Assyrian, and many more. To the Iraqi nationalists, the historical and cultural development of the nation has been based on the participation of many different religious and ethnic groups working together to create Iraqis' collective historical memory. (Davis, 2005) Both ideologies promoted a collective national identity which has been applied since the 1950s, particularly in Iraq, Syria, and Egypt. This collective national identity aimed to create a foundation and driving force behind their obsession with modernity. However, the presentation of a collective identity quickly collided with 
the complex social fabric of the states and their internal and external influences, resulting in pseudomodernised societies reflected through the production of material and immaterial entities.

After World War II (WWII), the role of design in the achievement of economic growth was promoted in association with development, and aimed to fulfil basic human needs. The United States clearly articulated these principles through a program President Harry S. Truman presented in his inaugural speech on the 20th of January, 1949: "Fourth, we must embark on a bold new program for making the benefits of our scientific advances and industrial progress available for the improvement and growth of underdeveloped areas." (Escopar, 1995, p. 36) In the historical context, design knowledge was applied to promote the production of handcrafts, which was treated as an important sector for its ability to support regional economic growth. ${ }^{3}$ (Escopar, 2018) At the same time, design practices were applied as a secondary layer to the production of quality crafts ready for export to international markets, specifically Western European markets. In this context, the design discourse promoted the "organic relationship that the crafts-person had with his works, and with his culture." (Saad, 2006, P 161) Overall, attempts to introduce the modern design discourse in the region, as well as in many other developing countries, reflected the specific contexts and practices of design in these countries. Furthermore, there was also the stagnation and disempowerment of design discourse in the region because of the longstanding promotion of traditional contexts and artistic practices throughout design education and learning practices dedicated to visually appealing and craft-oriented artefacts.

Design discourses presented in the region, specifically in Lebanon and Iraq, were treated as a manifestation of modernity through graphic design education in Lebanon and architecture in Iraq. Available financial resources in the country supported Iraq as a pioneering state in the region, which can be seen in the profound early attempts to build modern infrastructure projects for water management, transportation, urbanisation, and social services. All of these resources maintained the creation and growth of the new middle class, which were the leading group initiating a culturally-oriented transformation of Iraq into a modern state. In this context, the Iraqi Development Board (IDB) was established by the Iraqi government in the early 1950s to strategically plan, oversee, and utilise funding from foreign creditors and increased export revenue from the Iraqi oil industry to modernise the country and improve the living conditions of Iraqis. Building on the IDB's goal to achieve modernisation and enhance the country's materialisation, the IDB presented modern architecture as a symbol and core element in the progression towards a modern lifestyle, represented through building styles capable of strengthening national identity (Bernhardsson 2008). Through this vision, Baghdad became a prominent location for world-class architects, offering them the opportunity to create pioneering modern architecture in the region. The IDB commissioned a world-class architect and urban planner, Constantinos A. Doxiadis, ${ }^{4}$ to create the master plan of Baghdad and other major Iraqi cities. Furthermore, the IDB assigned another strategic project to Doxiadis concerning an ambitious modern housing project targeting the expanding Iraqi middle class in Baghdad and other major Iraqi cities. The project defined such housing as "the science of human settlements" (Pyla 2008, P 99) and was guided by a strategic vision to modify the modern architecture solution to fulfil basic human needs, (figure-1). Moreover, the IDB invited key international architects to design specific projects in Baghdad: Le Corbusier was commissioned to build a mammoth sports stadium; Walter Gropus from the Architects Collaborative was asked to design Baghdad University campuses (figure-2); Alvar Aalto was invited to

\footnotetext{
${ }^{3}$ In Jordan, the US 'Point Four' program focused on technically and financially supporting local craftsmen through design consultation, grants, and services, with a local community development foundation established for this purpose. The Walter Dorwin Teague Association in America studied the Jordanian handicrafts industry in 1950s, and the study was later implemented as a strategic plan to develop a number of NGOs to support craft sector production, training, and marketing in Jordan. (Saad, 2006, P 161)

${ }^{4}$ http://www.doxiadis.org/
} 
design a civic centre; and Frank Lloyd Wright was commissioned to design the Baghdad opera house. The IDB also supported pioneering Iraqi architects, commissioning Mohamed Makiya, Kahtan Awni, and Rifat Chadirji to design many public and private buildings.

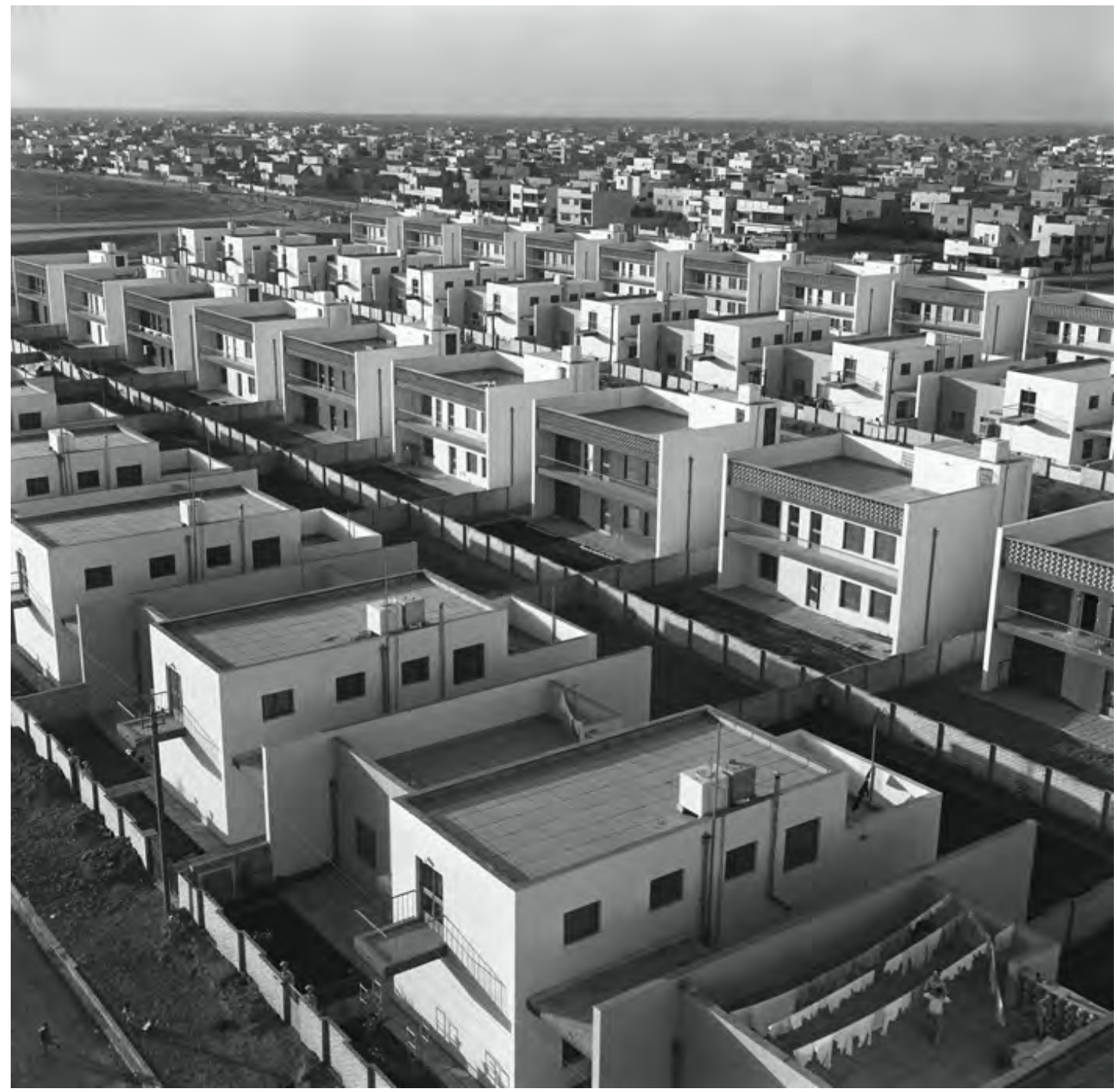

Figure-1: Constantinos A. Doxiadis (1950's) the modern housing for the Iraqi's middle class 


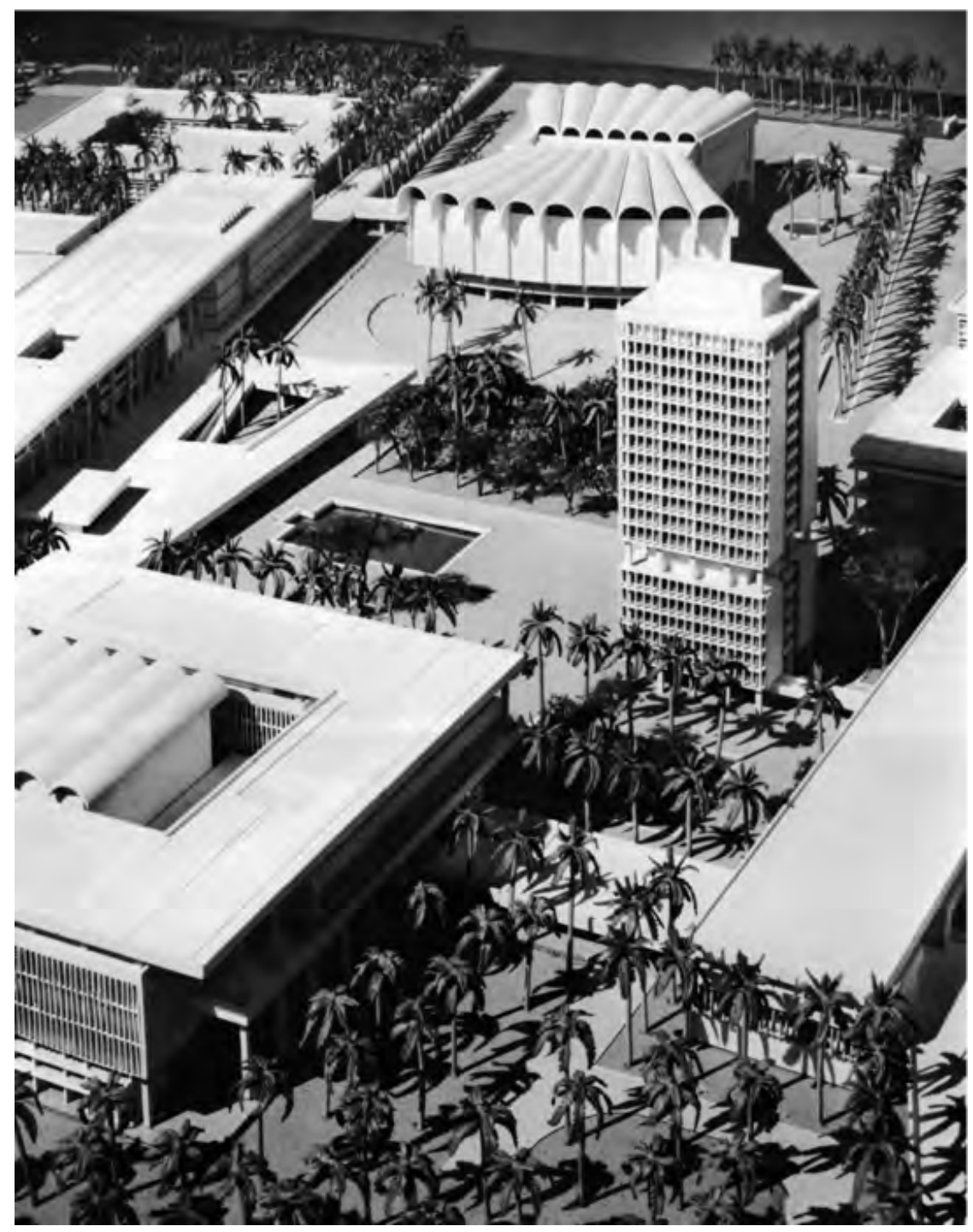

Figure-2 : Walter Gropus (1950's) Baghdad University campuses

In association with this move toward urbanisation and a modern lifestyle, proof of development and modernisation of sociocultural norms spread across the EMR. Many examples can be found in Iraq, showing how the materialisation and development of Iraqi architecture were associated with establishing the EMR's pioneering cultural movements and creative practices in visual arts and literature.

1. The modern visual arts movement in Iraq: The practice of contemporary visual art in Iraq was introduced early in the $20^{\text {th }}$ Century and was influenced by interactions with the modern art styles of Europe and the methods of teaching and practising visual art in Iraq. Those practices supported the establishment of modern art education in the early 1930s, when the Institute of Fine Arts was established in Baghdad. This institute offered programs in visual arts, music, drama, and design. The practice of modern arts was promoted and enthusiastically received by the middle class in many Arabic societies in Iraq, Syria, Lebanon, and Egypt. Furthermore, it was also promoted as the beginning of a radical new era in the sociopolitical context of these countries. (Shabout, 2012) 
2. The modern literary movement in Iraq: The creative, relatively open, and stable political setting of the monarchical period in Iraq (1921-1958) enabled intellectuals and writers to discuss Iraqi identity, emphasising its Arabic origin and its close links with ancient Iraqi civilisation. This emerged through a variety of creative writing in poetry and other literary forms that appeared in print and visual media. One of the major transformations toward modernity in Arabic literature occurred in Iraq in the late 1940s when one of the greatest Arabic poets, Badr Shakir al-Sayyab (1926-1964), began his literary experiments and drove classical Arabic poetry in a more modern direction. A group of creative Iraqi writers known as the Ruwwad (Pioneers) presented the new "free verse" model of Arabic poetry. ${ }^{5}$ These creative writers and others revolutionised the form, context, and content of Arabic poetry with the aim of repositioning this important creative writing away from its classical forms and freeing it from its previously heavy linguistic role. This allowed for further engagement in contemporary lifestyles, with a focus on tackling new dimensions of the modern social and political issues. (al-Musawi 2006)

Postcolonial politics in Iraq have been strategically driven by development and modernity since the 1940s. They have benefited from a relatively open and stable political order that has supported engaging in modern practices, during "the mid-1950s, Iraq seemed to have a hugely promising future, perhaps as 'a kind of Oriental Canada." (Mackintosh-Smith 2019: 490) This strategic vision was applied effectively and reflected in the rapid social progress that supported the rise of the middle class, particularly in the country's big cities. Throughout the EMR, the postcolonial era enhanced society's transformation toward a modern lifestyle. This can be seen in the expansion of cultural practices, media, TV, cinema, and many more, in addition to a similar expansion of social services. The movement toward modernisation focused on practices that developed slowly and steadily in society, which were informed by material and immaterial production. These practices included:

- Rapid movement toward building the country's infrastructure, which was directly aligned with the Western context of development at the time-i.e., materialisation and economic growth.

- Improving urban planning in the regional major cities and providing modern services such as water and electricity. Additionally, it helped to expand modern transportation networks, such as roads, ports, and airports across the region.

- Strengthening the modernisation of creative cultural practices through active social engagement, which in turn supported the formation of modern sociocultural practices and civil society groups such as trade unions and political parties.

- Supporting the need of technological transformation for a specialised workforce, which was reflected through the expansion of basic education outside major cities where new schools and technical institutions were established. Additionally, supporting the establishment of higher education and government sponsorship of local graduates to continue their postgraduate studies at European and American institutions.

- Enhancing the modernisation of sociocultural practices through the expansion of print publications and the establishment of a TV service in the early 1950s.

Emerging design discourses during this era were influenced by the 'utopian' context reflected by the principles, elements, and achievements of 'international style' in Europe and the USA. This fostered a tendency "to link designer's concerns with how things should be made to larger philosophical issues about how society should be organised and how human beings can best live." (Parsons, 2016, P 106)

\footnotetext{
${ }^{5}$ Among the many members of the group, this movement was led by Badr Shākir al-Sayyāb with active participation from Nāzik al-Malā'ikah (1923-2007), Buland al-Haydarī (1926-1996), and Abd al-Wahhāb al-Bayātī (1926-1999).
} 
Furthermore, the utopian context involved the unified role of the designer that related to a concern with "improving people's way of living by means of design." (Dorrestijn, 2013, P 46) Advancements in technology directed design practices away from traditional art and crafts and toward further engagement with technology, represented through the mass production of everyday objects and utilisation of interdisciplinary knowledge in the design process. The postcolonial era established creative bases for EMR societies to build on and to enhance further development of design discourses during the upcoming eras.

\section{Design as a manifestation of identity}

This vibrant era culminated in the late 1960s-1980s, after a period of sociopolitical instability ended with dictating political orders in countries such as Egypt, Syria, and Iraq. Regionally, it was the era of growing nationalist ideology, which was gradually enforced after the military coup over the liberal kingdom in Egypt in 1952, Iraq in 1958, and followed by waves of other military coups in Iraq and Syria. These coups ended with the Arab Socialist Ba'ath Party dictating the political order in both countries. The Iraqi Ba'ath party, "despite its tyranny and megalomania, did enact a considerable campaign to utilise Iraq's rich cultural heritage in order to develop degrees of national identity and social cohesion since its rise in 1968." (Isakhan 2011, P 259) The regional sociopolitical rhetoric - Egypt's in particular, engaged with other developing countries to shape the political movement of the non-aligned countries which were created after the Bandung Conference in 1955. New independent Asian, African, and Latin American countries agreed to cooperate economically and culturally to oppose colonialism or neocolonialism. ${ }^{6}$ The movement's first meeting was later in 1961 and, according to Mignolo, developing countries "made visible the hidden face of modernity, that is, coloniality" (Mignolo, 2011, P 52) and also addressed a politically complex scenario outside the tension of the Cold War between Western and Eastern powers. Furthermore, the non-aligned countries

make a distinction between decolonisation and decoloniality. 'Decolonisation' describes... their struggles to detach themselves from both capitalism and communism. Decolonisation is a 'third option,' but not in between democracy and socialism, capitalism and communism. It is an option that implies the decolonisation of democracy and socialism and, hence, capitalism and communism. (Mignolo, 2011, p.p. 52-53)

Additionally, decades of international instability and Cold War tensions empowered the developing countries to search for alternative solutions to strengthen their development strategies. In this context, design discourse was promoted as a creative practice that aimed to empower developing countries to move toward enhanced industrialisation as a means of modernisation and development. This move aligned with previous locally- and internationally-oriented attempts presented through design theory, design education, and professional design practices during the 1960s-70s that promoted utilising design discourse to encourage industrialisation as a means of social and economic growth. (Gwendolyn, 2017)

\footnotetext{
${ }^{6}$ The first large-scale Asian-African or Afro-Asian Conference-also known as the Bandung Conference (Indonesian: Konferensi Asia-Afrika) — was a meeting of Asian and African states, most of which were newly independent, which took place on April 18-24, 1955 in Bandung, Indonesia. The twenty-nine countries that participated at the Bandung Conference represented nearly one-quarter of the Earth's land surface and a total population of 1.5 billion people, roughly $54 \%$ of the earth's population at the time. [1][2] The conference was organised by Indonesia, Burma, Pakistan, Ceylon (Sri Lanka), and India, and was coordinated by Ruslan Abdulgani, Secretary General of the Indonesian Ministry of Foreign Affairs. The conference's stated aims were to promote Afro-Asian economic and cultural cooperation and to oppose colonialism or neocolonialism by any nation. The conference was an important step toward the Non-Aligned Movement.

(https://en.wikipedia.org/wiki/Bandung_Conference) retrieved $29^{\text {th }} / \mathrm{Sept} / 2017$
} 
The non-aligned movement's major contribution to design discourses in developing countries was introduced through the promotion of 'Design for Development,' which was introduced politically when the 'Ahmadabad Declaration' was issued in India in 1979. The declaration resulted from joint efforts between the United National Industrial Development Organisation (UNIDO), the International Council of Societies of Industrial Design (ICSID), and the Indian National Institute of Design (NID). The document clearly proposed the engagement of design with development as 'the right way' to do design in developing countries. Additionally, the document marked the "first time that industrial design had been suggested as worthy of inclusion in national development plans." (Coward, 2005, p.545) The declaration's major principles articulated that:

(1) Design is a powerful force capable of improving the quality of life of developing countries' populations. (2) Designers should understand and recognise the values of their societies and reflect them in their designs. (3) Designers should utilise both local, traditional resources and modern science and technology. (4) Designers should collaborate with one another to ensure that collective identities are preserved and the priorities of these collective identities are met. (Ahmedabad Declaration, 1979)

India was characterised as one of the non-aligned movement's leading countries and this fact was addressed as the political ideology that supported the establishment of the 'Ahmedabad Declaration.' As Margolin argued, "it was in the spirit of an aggressive call by the developing countries to restructure the world economy that the Ahmedabad conference was held and the declaration was produced." (Margolin, 2006, P 3) Iraq was the only EMR country to sign the Ahmedabad Declaration and specifically implement its principles in design education- the industrial design programme established in the mid 1970s. (Saad, 2013) However, the 'Ahmedabad Declaration' continues to be the only official document at the international level that articulates the strategic role of design discourse and practices in the development of developing countries. Additionally, the document articulates the spirit of modernity by shifting design from its local and traditional context toward enhancements in the modern context. As Parsons writes: 'What the Modernists sought, therefore, was not to turn design into 'fine art' or tradition-based craft, but to blend the best elements of traditional craftsmanship, modem mass production and fine art into a new way of producing material goods that made sense in the social context of contemporary life." (Parsons, 2016, p.46) This context enforced the nature of interdisciplinary knowledge and practice that culminated in the design process in terms of innovation, visualisation, production, making, and promotion. These practices identified design as a 'micro' element within industrialisation and production processes, whereas the nature of design practices as experimental shows, overwhelmingly, that design plays a 'macro' role in efforts to achieve human development goals in developing countries. Such arguments supported the value many governments placed on elevating design as a strategic factor in their development planning. Reflections addressed through new policiesthe 'design policy' or 'design and innovation policy'-utilise design discourse as the core of strategies for implementing and promoting the country; for example, design policy in Estonia and India.

The era established that 'development' and 'modernity' are synonymous and have been embedded in the political, economic, and social rhetoric of progress in developing countries since the mid- $20^{\text {th }}$ Century. Accordingly, 'modernisation' can be defined as "a want to have a comfortable, middle-class existence with all the amenities and attributes that go along with it-clean water, indoor plumbing, electricity, telecommunications, infrastructure, personal safety, rule of law, stable politics and a good education system." (Mignolo, 2011, P 47) However, the crises of modernity in many developing nations manifests politically and socially, with the endorsement of Westernisation and modernisation over traditional cultural practices being reflected in the deterioration of such practices in these conservative 
societies. Furthermore, the political reform in some of these nations is correlated with Western colonialism; such examples include the military coup in Iraq in 1958 to establish a socialist republican state over the kingdom. This dual vision continues to dominate and is reflected in regional politics, economics, and sociocultural practices. (Said, 2005) The influence of these broader political contexts is further reflected through new legislation some EMR countries issued that sought to promote the revival of traditional heritage and self-sufficiency concerning creative practices and the production of immaterial and material forms in the fields of architecture, fine arts, design communication, music, performing arts, etc.

The uprising of socialist politics enforced in these countries caused the states to gain significant control over socioeconomic affairs, reinforcing their superior position as the only employer of the workforce and increasing their direct control over the manufacture of material objects in the country. At the same time, progress toward modernisation and development has been promoted extensively during this era, led by intellectual modernity. According to Tagharobi, there are three waves that demonstrate transformation toward modernity in the Middle Eastern region:

Modern literary forms were primarily seen as a way of supporting social and political reform...Emphasis on domestic sources of thoughts and development under leftist influences, when the will to change was manifesting through nativism... and the last wave of intellectuals see the path toward change in analysing their own societies through modern critical disciplines and by adopting historical perspectives towards their contemporary issues... (Tagharobi, 2016)

Promoting cultural identity was a major goal of design discourses during this era in the EMR. Policies enforced design practices and design education to endorse and revive traditional visual elements. For example, the Iraqi government has enforced the use of selected visual elements from Islamic architecture when building the façade of new state buildings since the1970s. A policy mandating the use of Arabic at higher institutions is enforced in both Iraq and Syria, and moved further to ban the use of non-Arabic language, text, and fonts in all communication designs and branding campaigns. Those policies include all creative practices in fine arts, music, literature, and related fields. The strategy of building cultural identity involves a complex web of factors and requires planning based on a long-term process around enforced sociopolitical roles, which this example applied to design discourses in major EMR countries. In fact, those enforced roles banned the local design communities from building on previous achievements and communications with international design communities. Considering the government's tight control on communication channels at that time, many policies banned international journals, books, periodicals, TV programmes, etc. from being distributed locally. Further action was directed toward localising design education at all levels. This study considers the current retardation and chaos around design discourses in the EMR as a reflection of the sociopolitical actions enforced in the region during this era, specifically concerning design education.

\section{Autocracy and the expansion of the chaos}

Between the two rivers of Mesopotamia, I was born and raised in the city of Fallujah by a conservative, working-class family. My life was shaped and influenced by the Iraqi sociopolitical rhetoric of modernity and development. I began my university study in industrial design at the very end of the 1970s, influenced by a learning environment that aimed to enhance Iraq's progression toward industrialisation and make designs suited to local manufacturing capabilities, as a means to achieve self-sufficiency. I witnessed the expansion of the country's infrastructure; urbanisation and growth of new industrial production corporations created many consumer products for the local markets with the brand 'Made in 
Iraq' during the 1970s-1980s. Furthermore, I still remember the 'politically-oriented' recommendations that forced design practices to utilise revived historical and cultural motifs and symbols for new 'Iraqi' designs across communication, architecture, and other disciplines. Within a short period, the era showed quality examples of creative designs in architecture and visual arts. Unfortunately, the stability and development of these achievements degraded quickly, influenced by the series of wars, harsh economic embargoes, and the recolonisation of Iraq in 2003. Sadly, these events resulted in extensive retardation and empowered the current chaotic situation. However, since 1991, I've witnessed from my position in exile the gradual retardation not only in Iraq, but across the EMR's major countries. In such a complex situation, is design knowledge and practices useful? Can they provide alternative and innovative solutions for some major problems the EMR communities are facing?

There is an urgent need to transform EMR design discourses beyond their dominant arts and crafts context and practices. Future transformation means engaging design discourses socially by empowering social groups' capabilities and active engagement, through processes, to develop innovative and sustainable solutions. This theoretical vision relies on the innovative capabilities of design disciplines in utilising interdisciplinary/transdisciplinary knowledge to support the social groups tackling complex political, economic, and social challenges. This also means empowering the role of the designer as a social agent, able to support collective practices toward sustainable societies. In such contexts, we must (1) reconsider local designers' knowledge and practices in social innovation and embed their methods and principles in the core objectives of regional design education programmes, (2) support local designers to create professional networks capable of sustaining links and professional development collaboration locally, regionally, and internationally, and (3) acknowledge and support the recent, new design practices in the region, seen in communication design-oriented groups and activities such as:

- The MENA ${ }^{7}$ Design Research Centre, Lebanon: http://www.menadrc.org/about

- Amman Design Week, Jordan: http://ammandesignweek.com/index.php/about/overview

- 100 Best Arabic Poster, Egypt: http://100BAP.com

- The Font Lab, Egypt: http://www.facebook.com/typelabauc

We must also support the current social development organisations that continue to direct their activities and utilise design strategies and tools to broaden their scope and provide innovative social solutions. Many of these organisations exist across the region in Egypt, Jordan, Palestine, Lebanon, and recently in Iraq.

\section{References}

Ahmedabad Declaration on Industrial 'Design for Development' (1979). Scanned copy from archived documents at Prof. M. P. Ranjan Library, the National Institute of Design in Ahmedabad, India. Requested and delivered via personal email on 5 July 2007.

al-Musawi, Muhsin (2006) Reading Iraq: Culture and Power in Conflict. I.B. Tauris, London-UK

AlSayyad, N. (2008) From Modernism to Globalization: The Middle East in Context." In Modernism and the Middle East: Architecture and Politics in the Twentieth Century. Sandy I. and Kishwar R. (Edit's.) University of Washington Press, Seattle and London, 2008.

Bernhardsson, M. T. 2008. Vision of Iraq, Modernizing the Past in 1950s Baghdad. In Studies in Modernity and national Identity, ed. Sibel B. and Resat K. USA: University of Washington Press.

Cannadin, David (2002). Ornamentalism, How the British Saw Their Empire. Oxford: Oxford University Press Chadirji, R. (1995). Dialogue on the Structure of Art and Architecture. In Arabic. London: Riad El-Rayyes Books Ltd.

\footnotetext{
${ }^{7}$ MENA: Middle East and North Africa region, the UN term for the Arabic countries in Asia and Africa.
} 
Coward, T. \& Fathers, J. (2005). A critique of design methodologies appropriate to private-sector activity in development. Development in Practice, 15(3\&4), 451-462. London: Routledge.

Davis, E. (2005). Memories of State; Politics, History, and Collective Identity in Modern Iraq. Berkeley: University of California Press.

Dorrestijn, Steven and Peter-Paul Verbeek (2013) Technology, Wellbeing, and Freedom: The Legacy of Utopian Design. In International Journal of Design Vol. 7 No. 3.

Escobar, Arturo (1995) Encountring Development; the making and unmaking of the third world. Princeton University Press, Princeton, NJ.

Escobar, Arturo (2018) Design for the Pluriverse; Radical Interdependence, Autonomy, and the Making of Worlds. Duck University Press. Durham and London.

Faroqhi, Suraiya (2012) Artisans of Empire; Crafts and craftspeople under Ottomans. I. B. Tauris. London.

Gwendolyn Kulick (2017) Adding plus value to development aid projects through design strategy: experiences from Pakistan, The Design Journal, 20:sup1, S411-S423, DOI: 10.1080/14606925.2017.1352939.

Helfont, Samuel (2015) Post-Colonial States and the Struggle for identity in the Middle East since World War Two. Program on the Middle East. Butcher History Institute. http://www.fpri.org/article/2015/10/post-colonialstates-and-the-struggle-for-identity-in-the-middle-east-since-world-war-two/ (retrieved 30 th $/ \mathrm{Sept} / 2019$ )

Hourani, Albert. (2005). A History of the Arab People. Faber and Faber. London.

http://www.helwan.edu.eg/Applied-Arts/ Retrieved $4^{\text {th }} /$ Nov./2019

http://en.wikipedia.org/wiki/Bandung_Conference Retrieved 29

Isakhan, Benjamin 2011. Targeting the Symbolic Dimension of Baathist Iraq: Cultural Destruction, Historical Memory, and National Identity. In Middle East Journal of Culture and Communication 4.

Mackintosh-Smith, Tim (2019) Arabs; A 3000-Year History of Peoples, Tribes and Empires. Yale University Press, New Haven \& London.

Margolin, V. (2006). Design for Development: towards a history. DRS International Conference-Wonderground. Lisbon, Portugal.

Mignolo, Walter D. 2011. The Darker Side of Western Modernity: Global Future, Decolonial Options. USA: Duke University Press.

Parsons, Glenn (2016) The Philosophy of Design. Cambridge: Polity Press.

Pyla, Panayiota. 2008. Baghdad's Urban Restructuring, 1958 Aesthetics and Politics of Nation Building. In Studies in Modernity and national Identity, ed. Sibel B. and Resat K. USA: University of Washington Press.

Saad, Q. (2006) Design for Development; Case Studies from Jordan. In Ken Friedman, Terence Love and Eduardo Corte-real [Ed] [2006] Design Research Society, Wonderground-International Conference 2006. Instituto de Artes Visuais, Design e Marketing-IADE. CEIADE, Lisbon-Portugal. P. 161

http://www.iade.pt/drs2006/wonderground/proceedings/abstracts_list.pdf http://www.doxiadis.org/ Retrieved March/2020

Saad, Qassim (2013), Framework for revisioning design in Iraq. PhD thesis, School of Architecture and Design, Royal Melbourne Institute of Technology, RMIT University http://researchbank.rmit.edu.au/view/rmit:160509

Said, Edward W. (2005) From Oslo to Iraq the Roadmap. Bloomsbury-UK

Shabout, Nada. (2012) Bifurcations of Iraqi's Visual culture. In We are Iraqis; Aesthetics and Politics in a time of War, ed. Nadje A. and Deborah N. New York: Syracus University Press.

Tagharobi, K. and Ali Z. (2016) Modernism in the Middle East and Arab World 10.4324/9781135000356-REMO14-1 09/05/2016 http://www.rem.routledge.com/articles/overview/accommodating-an-unexpected-guest (Retrieved 30 Sept. 2018) 


\section{Dr Qassim Saad}

An Iraqi industrial designer living in exile since 1991, holding BA, MA \& PhD in Industrial Design. He taught design and assigned for academic leadership roles since 1984 in Iraq, Jordan, New Zealand, Egypt, Germany, and recently here in Australia. Saad understanding of design is providing the stimulus for future- looking, dynamic approaches to innovation, building on its nature as inter-disciplinary and applied knowledge culminated by creative practices. The landscape of design education is changing around the globe where design schools are transforming into centres of collaboration, utilising new knowledge in science, engineering and social sciences in the process to designing new applications, services, and systems. The process has empowered the creation of further specialised new design disciplines, with innovative teaching practices including broader inter- and trans-disciplinary research scholarship. Saad research embraces creative practice outputs and traditional scholarly publications related to design and social innovation 'outside the centre.' Aim to articulates future scope to empower societies, in developing countries, particularly achieving a better quality of life, through applying design methods and practices, as strategic tools, to facilitate their social systems mega problems. ORCID: 0000-0002-5641-9957 